\author{
ANNALS OF THE \\ UNIVERSITY OF CRAIOVA
}

Series: $\begin{aligned} & \checkmark \text { Biology } \\ & \checkmark \text { Horticulture } \\ & \checkmark \text { Food products processing } \\ & \text { technology } \\ & \checkmark \text { Environmental engineering }\end{aligned}$

\author{
Vol. XXVI (LXII) - 2021
}

\title{
CHLOROPHYLL, CAROTENOID AND FLAVONOID CONTENTS IN VEGETATIVE ORGANS OF VICIA FABA L.
}

\author{
Popoviciu Dan Răzvan ${ }^{1 *}$, Panaitescu Liliana ${ }^{1}$ \\ ${ }^{1}$ „Ovidius” University of Constanţa, Faculty of Natural Sciences and Agricultural Sciences, \\ Constanţa, Romania \\ *Correspondence author. E-mail: dr_popoviciu@yahoo.com
}

Keywords: Vicia faba, chlorophylls, carotenoids, flavonoids

\begin{abstract}
Leaf and stem tissues of broad bean (Vicia faba L.) were analyzed for chlorophyll, carotenoid and flavonoid concentrations.

Total clorophyll concentration was $6,258 \mathrm{mg} / \mathrm{kg}$ in leaves and $570 \mathrm{mg} / \mathrm{kg}$ in stems, with a dominance of chlorophyll a 2.2-2.4:1 ratio. Average carotenoid concentration reached 4,317 $\mathrm{mg} / \mathrm{kg}$ in leaves and $404 \mathrm{mg} / \mathrm{kg}$ in stems. Flavonoids had elevated concentrations, with an average of $108,179 \mathrm{mg} / \mathrm{kg}$ in leaf tissue and five times lower, $20,423 \mathrm{mg} / \mathrm{kg}$ in broad bean stems. These values make broad bean a valuable forage plant.
\end{abstract}

\section{INTRODUCTION}

Broad bean (Vicia faba L.), also known as faba bean, horsebean etc. is one of the most important agricultural plants in the Fabaceae family (the third most cultivated, after soybean and peas. A native of the Near East and North Africa, it has quickly become a popular crop throughout the World (in China, for example, it has been cultivated for 5,000 years).

It is an annual herbaceous plant, with erect, 0.3-2 $\mathrm{m}$ tall stems, alternate compound leaves (with few or no tendrils), large, usually white flowers, with purple spots, grouped in axillary racemes and short, broad pods (Singh et al. 2013).

Broad bean is mostly cultivated for its seeds, a source of protein, carbohydrates, as well polyphenols and other antioxidants, its popularity in human alimentation increasing in recent times (Sathya Prabhu \& Devi Rajeswari 2018). Other uses include soil regeneragtion through nitrogen fixation and forage.

Apart from seeds, vegetative organs (leaves and stems) are used as a forage. Good forage cultivars have stems with low branching and low lignin content and over 20 photosynthetically-active leaves at the time of cutting, with a high overall protein content (180-200 g/kg; Mihailović et al. 2011). This is why knowing the biochemical composition of broad bean vegetative organs is important in designing forage schemes.

Chlorophylls $a$ and $b$ are the main pigments found in green vegetative organs. They are an important part of human and animal nutrition, having antioxidant properties, limiting oxidative stress, digestive uptake of carcinogenic compounds and limiting kidney stone formation (Inanç 2011). 
Carotenoids such as various carotenes, lutein, lycopene, zeaxanthin etc. are accessory photosynthetic and protective pigments in plant organs. For human and animal organisms, they function as precursors of retinol and melanin (essential compounds for eye and skin health), while also having strong antioxidant properties (Eldahshan \& Singab 2013).

Phenolic and polyphenolic compounds form a wide group of phtyochemicals that protect plants against various infections and insect attacks. Among these, flavonoids (low-mass polyphenols) are extremely valuable nutrients, with high antioxidant, antiviral, antibacterial, anti-inflammatory and antiproliferative capacities (Kivrak \& Kivrak 2014).

\section{MATERIAL AND METHODS}

Plant material was collected from local farms in the Constanța County, Romania. Leaves and stems were sorted and analyzed separately.

For determining chlorophyll and carotenoid concentration, $0.1 \mathrm{~g}$ of fresh tissue were extracted in $10 \mathrm{~mL}$ acetone $(80 \%)$, filtered and the spectrophotometric absorbance was determined at 470, 647 and $663 \mathrm{~nm}$, using a S106 WPA spectrophotometer (Popoviciu et al. 2019). Concentrations were derived from absorbance values using specific equtions (Lichtenthaler \& Buschmann 2001).

For flavonoids, $1 \mathrm{~g}$ fresh tissue were extracted in $5 \mathrm{~mL}$ methanol, filtered and $0.5 \mathrm{~mL}$ aliquotes of the extract were diluted in $4: 8$ water:methanol solution. Spectrophotometric absorbance was read at $340 \mathrm{~nm}$ and concentrations were determined according to Szabo et al. 2012.

Dry biomass percentage was determined by drying fresh tissue at $105^{\circ} \mathrm{C}$. All concentrations were expressed as $\mathrm{mg} / \mathrm{kg}$ of plant dry weight.

\section{RESULTS AND DISCUSSIONS}

Average dry biomass percentage was $21 \%$ in stems and $35 \%$ in leaves.

Chlorophyll concentrations are shown in Fig. 1. Fig. 2 shows total carotenoid concentrations, while Fig. 3 shows flavonoid content in plant organs.

Total clorophyll concentration was $6,258 \mathrm{mg} / \mathrm{kg}$ in leaves and $570 \mathrm{mg} / \mathrm{kg}$ in stems, with a dominance of chlorophyll a 2.2-2.4:1 ratio. Chlorophyll concentrations found in broad bean leaves are thus similar to those found in vegetative organs of some common pasture grasses ranging from 3,220 to $15,300 \mathrm{mg} / \mathrm{kg}$, also with a dominance of chlorophyll a (Bokari 1983). It was higher than in lettuce and nettle leaves (226, respectively $456 \mathrm{mg} / \mathrm{kg} \mathrm{FW}$; Morna 2015).

Average carotenoid concentration reached $4,317 \mathrm{mg} / \mathrm{kg}$ in leaves and 404 $\mathrm{mg} / \mathrm{kg}$ in stems. This is higher, for instance, than values found in forage rye (Secale cereale) - up to $271 \mathrm{mg} / \mathrm{kg}$ (Zhao et al. 2020) - or lettuce and nettle (45-74 mg/kg FW; Morna 2015).

Flavonoids had elevated concentrations, with an average of $108,179 \mathrm{mg} / \mathrm{kg}$ in leaf tissue and five times lower, $20,423 \mathrm{mg} / \mathrm{kg}$ in broad bean stems. For comparison, red clover, Trifolium pratense, contains up to $37,800 \mathrm{mg} / \mathrm{kg}$ flavonoids (Tava et al. 2015), alfalfa, Medicago sativa - 12,000 mg/kg (Karimi et al. 2013). Mulberry leaves (Morus sp), used as forage in many Asian countries contain up to $58,400 \mathrm{mg} / \mathrm{kg}$ total flavonoids (Hassan et al. 2020). Such high flavonoid contents are even comparable to those in tea leaves (Blumberg et al. 2015). 


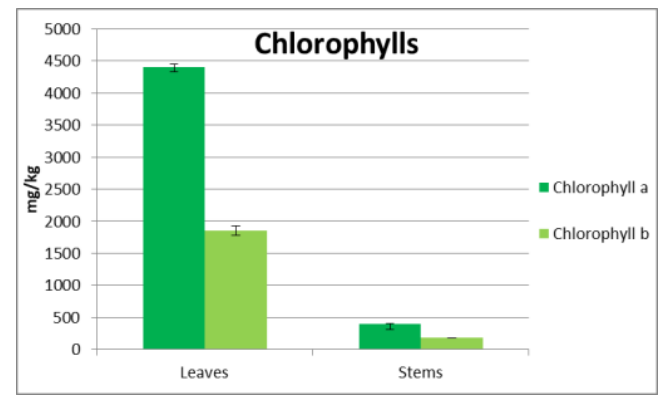

Figure 1. Chlorophyll a and b concentration in Vicia faba tissues $(\mathrm{mg} / \mathrm{kg})$.

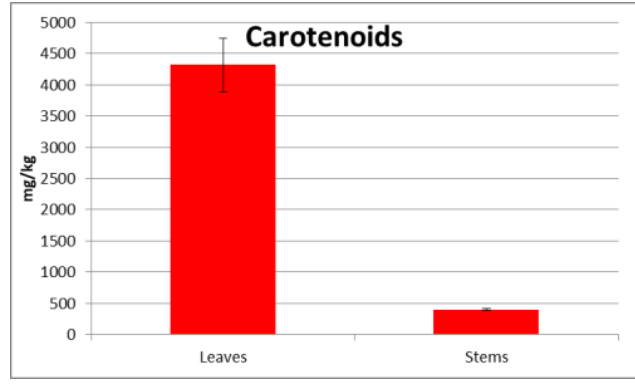

Figure 2. Total carotenoid concentration in Vicia faba tissues $(\mathrm{mg} / \mathrm{kg})$.

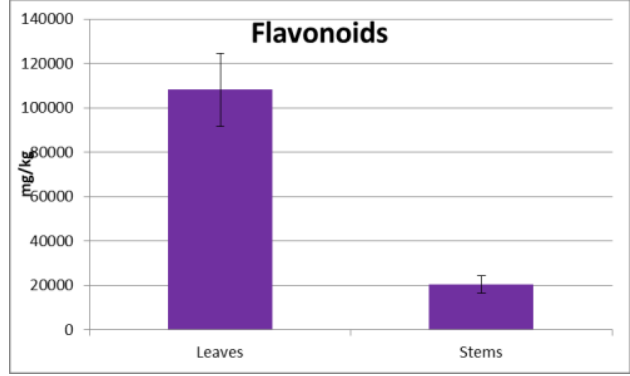

Figure 3. Total flavonoid concentration in Vicia faba tissues $(\mathrm{mg} / \mathrm{kg})$.

\section{CONCLUSIONS}

With high chlorophyll and carotenoid content (up to $6,258 \mathrm{mg} / \mathrm{kg}$, respectively, $4,317 \mathrm{mg} / \mathrm{kg}$ ), broad bean tissues, especially foliar ones, are comparable to common forage plants.

Flavonoid contents are even higher, with up to $108,179 \mathrm{mg} / \mathrm{kg}$ in leaf tissues. These values are higher than most forage plants and offer a valuable source of antixidants.

These results show a high potential for broad bean vegetative organs as a forage, but also for other possible applications.

\section{REFERENCES}

Bokari U.G. 1983. Chlorophyll, dry matter, and photosynthetic conversionefficiency relationships in warm-season grasses. J. Range Manag., 36(4), 431-434. 
Blumberg J.B., Bolling B.W., Chen C.Y.O., Xiao H., 2015. Review and perspective on the composition and safety of green tea extracts. European J. Nutr. Food Saf., 5(1), 1-31.

Eldahshan O.A., Singab A.N.B. 2013. Carotenoids. J. Pharmacogn. Phytochem., 2(1), 225-234.

Hassan F., Arshad M.A., Li M., Rehman M.S., Loor J.J., Huang J. 2020. Potential of mulberry leaf biomass and its flavonoids to improve production and health in ruminants: mechanistic insights and prospects. Animals, 10, doi:10.3390/ani10112076.

Inanç A.L. 2011. Chlorophyll: structural properties, health benefits and its occurrence in virgin olive oils. Akademik Gıda, 9(2), 26-32.

Karimi E., Oskoueian E., Oskueian A., Omidvar V., Hendra R., Nazeran H. 2013. Insight into the functional and medicinal properties of Medicago sativa (Alfalfa) leaves extract. J. Med. Plants Res., 7(7), 290-297.

Kivrak I., Kivrak S. 2014. Antioxidant properties, phenolic profile and nutritional value for Sorbus umbellata fruits from Turkey. Austin J. Nutr. Food Sci., 2(8), 10431048.

Lichtenthaler H.K., Buschmann C. 2001. Chlorophylls and carotenoids: Measurement and characterization by UV-VIS spectroscopy. In Wrolstad R.E. (ed.), Current Protocols in Food Analytical Chemistry, John Wiley \& Sons Inc., Hoboken, F4.3: 1-8.

Mihailović V., Mikić A., Ćupina B., Krstić Đ., Antanasović S., Erić P., Pataki I. Faba bean as a forage, biofuel and green manure crop. Grain Legumes, 56, 34.

Morna A. 2015. Chlorophyll and carotenoid content in lettuce (Lactuca sativa L.) and nettle leaves (Urtica dioica L.). Analele Univ. Oradea, Fascicula: Ecotoxicologie, Zootehnie şi Tehnologii de Industrie Alimentară, 14, 243-248.

Popoviciu D.R., Ionașcu, D.C., Bercu R. 2020. Comparative quantitative analysis of some classes of bioactive compounds in six green tea types available on the Romanian market. Ann. Univ. Craiova, Ser. Biol. Hortic. Food Prod. Process. Environ. Eng., 25(61): 167-172.

Sathya Prabhu D., Devi Rajeswari V. 2018. Nutritional and biological properties of Vicia faba L.: A perspective review. Int. Food Res. J., 25(4), 1332-1340.

Singh A.K., Bharati R.C., Manibhushan N.C., Pedpati A. 2013. An assessment of faba bean (Vicia faba L.) current status and future prospect. Afr. J. Agric. Res., 8(50), 6634-6641.

Szabo I., Vonhaz G., Fodor A., Bungău S., Țiț D.M. 2012. The quantitative analysis through spectrophotometry of flavonoids and polyphenols from vegetable products Hibisci trioni herba, radix and fructus. Analele Univ. Oradea, Fascicula Protecția Mediului, 18, 73-80.

Tava A., Pecio L., Stochmal A., Pecetti L. 2015. Clovamide and flavonoids from leaves of Trifolium pratense and T. pratense subsp. nivale grown in Italy. Natural Product Communications, 10(6), 933-936.

Zhao G.Q., Wei S.N., Li Y.F., Jeong E.C., Kim, H.J., Kim, J.G. 2020. Comparison of forage quality, productivity and $\beta$-carotene content according to maturity of forage rye (Secale cereale L.). Journal of the Korean Society of Grassland and Forage Science, 40(3), 123-130. 